\title{
University of New Hampshire
} Carsey School of Public Policy

\section{CDFIs and Online Business Lending}
A Review of Recent Progress, Challenges, and Opportunities

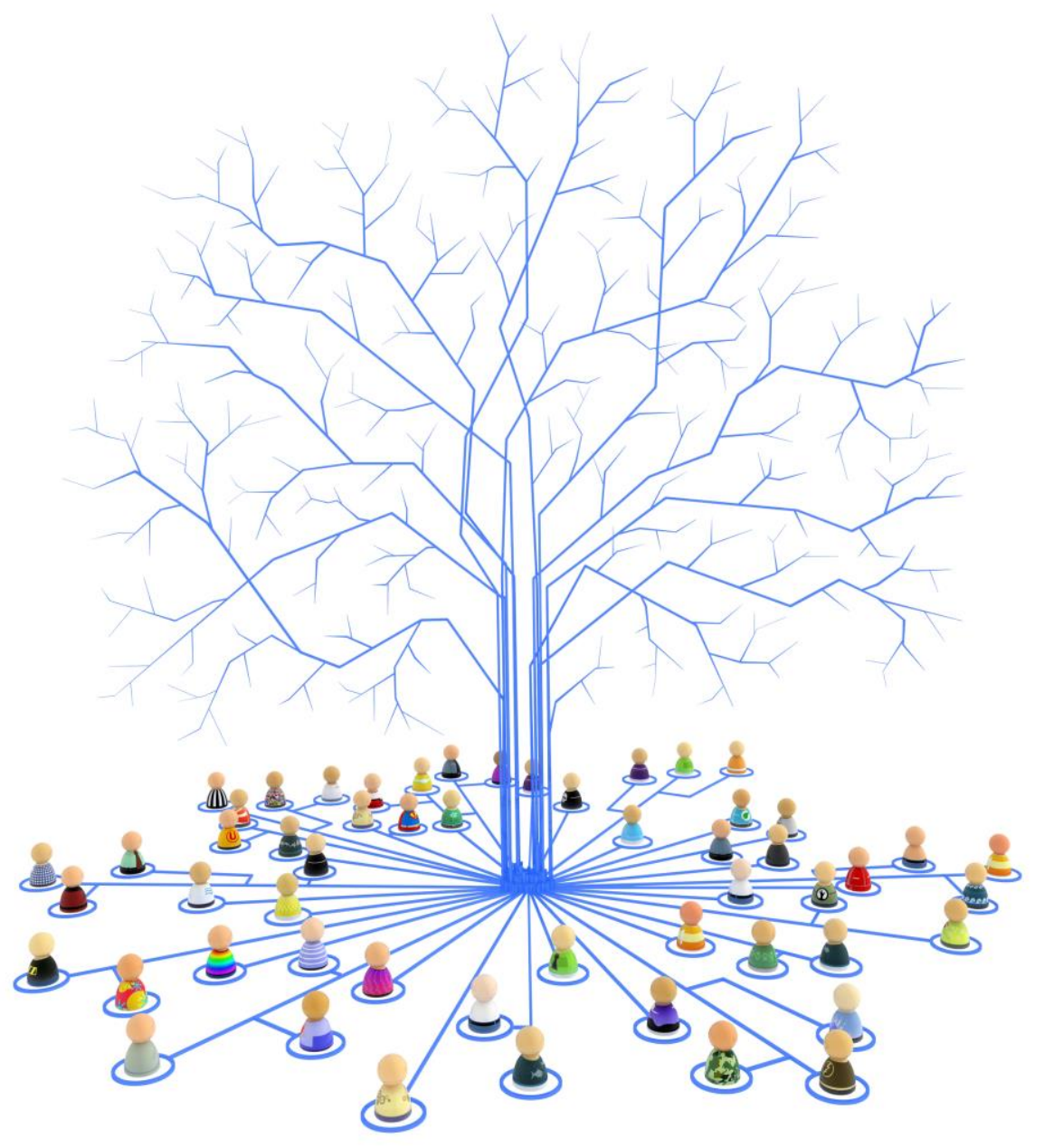

By Jack Northrup, Eric Hangen, and Michael Swack Center for Impact Finance at the Carsey School of Public Policy 


\section{Table of Contents}

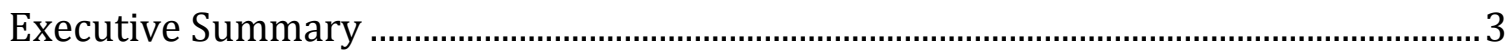

A Brief Overview of the Online Business Lending Industry …………………………….....

Small Business Capital Needs in the United States and the Emerging Role of Online Lenders ................................................................................................................

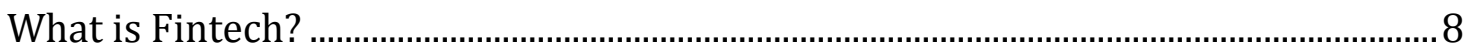

Online Lending Business Models ...………………………………………………....9

Online Small Business Lending Products.................................................................... 11

Industry Growth Trends and Scale............................................................................ 13

Portfolio Performance.................................................................................................... 14

Consumer Concerns ................................................................................................... 15

A Brief Overview of CDFIs and Their Role in Business Lending..................................... 16

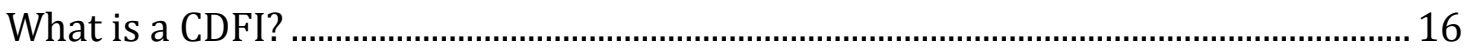

CDFI Impacts in Small Business Lending ..................................................................... 17

Issues of Scale and Operating Efficiency in the CDFI Industry ……………………..... 18

Recent CDFI Efforts to Work with Fintech in Business Lending .................................... 19

Opportunity Fund / Lending Club Partnership .............................................................. 20

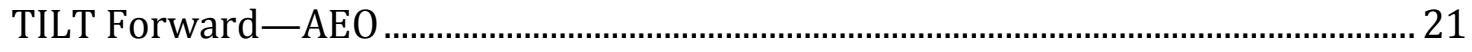

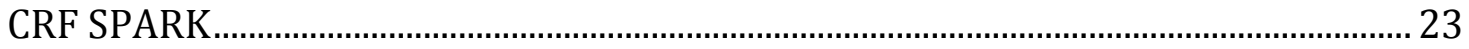

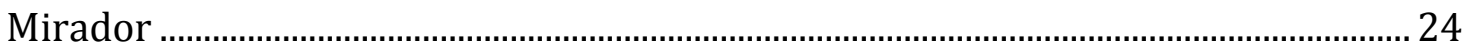

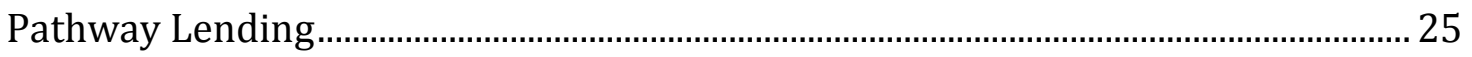

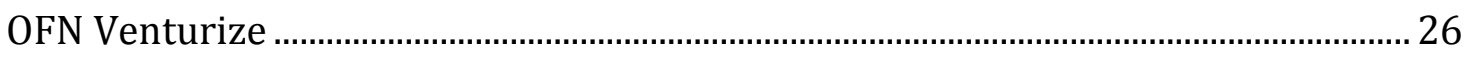

Observations from Industry Stakeholders on Opportunities and Challenges for Business Lending CDFIs ................................................................................................. 26

Key Themes Emerging from Stakeholder Interviews .................................................... 27 


\section{Executive Summary}

In March 2015, the Center for Impact Finance at the Carsey School of Public Policy at the University of New Hampshire convened the 16th Annual Financial Innovations Roundtable at the Federal Reserve Board in Washington, DC. The objectives of the proceedings were:

1. To understand changes in the small business lending marketplace that affect community development lenders and the small business customers they serve

2. To identify and begin to advance ways for Community Development Finance Institutions (CDFIs) and other mission-based lenders to take advantage of, and shape technological developments that can improve small business access to credit and encourage growth of the small business lending marketplace Online marketplace lending refers to the segment of the financial services industry that uses investment capital and data-driven online platforms to lend either directly or indirectly to consumers and small businesses. This segment initially emerged as a "peer-to-peer" marketplace, with companies giving individual investors the ability to provide financing to individual borrowers. As products and business models have evolved, the investor base for online marketplace lenders has expanded to institutional investors, hedge fund, and financial institutions. In recognition of this shift in investor base, the market as a whole is no longer accurately described as a "peer-to-peer" market. Accordingly, we refer to these companies as "online marketplace lenders."

US Department of the Treasury. 2016. "Opportunities and Challenges in Online Marketplace Lending." https://www.treasury.gov/connect/blog/Documents/Opportunities_a nd_Challenges_in_Online_Marketplace_Lending_white_paper.pdf

Sam's Club Giving has provided the Carsey School of Public Policy research funds to examine the emerging online small business lending sector-a part of the broader "fintech" (financial technology) sector-and its relationship to and effects upon CDFIs. The Carsey School conducted 25 interviews with both CDFIs and online business lending industry stakeholders, compiled data and reviewed literature on the current state of both industries, and examined initiatives in which CDFIs are partnering with online business lenders or are applying fintech in some way to their work.

Several key themes emerge from this research.

Online small business lenders are greatly outpacing the CDFI industry in terms of the number and volume of loans they are producing.

Leading online lenders are now originating billions of dollars in loan volume per year-for example, in 2015, LendingClub made $\$ 11.4$ billion (which includes both business and consumer loans) and OnDeck made $\$ 1.6$ billion in loans. CDFI Fund statistics suggest that the entire combined CDFI industry would be a small player next to these lenders. The most recent CDFI Fund statistics are for 2014, and only CDFIs that have received awards from the Fund in recent years are required to 
report. All reporting CDFIs indicated making \$685 million in business loans in $2014 .{ }^{1}$

Individual CDFIs, even leading ones, have much smaller volumes. For example, according to financial audit data, in 2015, Opportunity Fund lent $\$ 37$ million, Coastal Enterprises $\$ 20.6$ million, and Craft 3 \$77.4 million. Small CDFIs may originate less than $\$ 1$ million in business loans in a given year.

This disparity is also seen when looking at the number of loans made. OnDeck, for example, made 37,141 loans in 2015, compared to 4,078 for all reporting CDFIs in 2014.

Some of the competitive advantages that online lenders employ to achieve this higher level of production include technology that enables much faster customer response times, greater investment in marketing and customer acquisition, and scaled relationships with the capital markets (which are in turn enabled by the design of loan products with market returns).

Nevertheless, CDFIs have unique capabilities that could help them continue to be relevant and impactful players in the business lending space, provided they can adapt to the new environment.

Both online lenders and CDFI stakeholders we interviewed recognized the ability of CDFIs to provide borrower education and technical assistance. Some interviewees viewed this ability as complementary to online lenders' ability to deliver loans, while others saw this ability as a way for CDFIs to lend to a class of borrowers that other lenders cannot reach. A number of interviewees cautioned, however, that to the extent that CDFIs rely on craftsman-like, "high touch" methods, they will fail to achieve scaled impact and will suffer serious disadvantages in terms of the cost and timeliness of loan production. CDFIs are thus left with the difficult challenge of attempting to use new technology to streamline their operations as much as possible, while still offering some of the unique customer service that sets them apart.

Some interviewees highlighted product differentiation as a strategy for CDFIs. This is exemplified by the comment from Jacob Haar of Community Investment Management: "What CDFIs are doing is so much better for the borrower." CDFIs may indeed have opportunities to educate business owners that borrowing from them is a better option, to serve borrowers who have been denied by online lenders, and even to assist borrowers who need to unwind debt from online lenders. On the other hand, CDFIs have been constrained in capitalizing these products, and may need to adopt more standardized products if they want to scale up their lending activity. Moreover, other interviewees felt that CDFIs actually lack product diversity and thus do not have a competitive advantage over online platforms.

${ }^{1}$ Analysis of FY 2014 CDFI Fund CIIS Data Release. 
Fintech in general, and the growth of online business lending in particular, present new opportunities for CDFIs to create new marketing channels, generate operating efficiencies, access capital, and improve customer service.

Most interviewees believed there was significant potential for business lending CDFIs to improve their business results by adopting new financial technology, whether through partnerships with online lenders or through other pathways towards platform development. While most comments centered on opportunities to gain efficiencies in core operations and underwriting, other interviewees talked about how financial technology could help to improve the customer experience or access new capital. One example of the latter opportunity is the TILT Forward Initiative, in which CDFIs can access customers referred by banks and nonbank lenders as well as credit products from third parties capitalized through a wholesale relationship with Dream Fund.

In addition to the TILT Forward Initiative, there are a number of other specific business opportunities in which business lending CDFIs that have not yet integrated fintech strategies could participate. We describe a number of these specific business opportunities for CDFIs, such as partnerships with online lenders and fintech companies, in the body of the report.

CDFIs that are unable to adapt may be left behind. This creates concern about whether and how smaller CDFIs, as well as CDFIs who wish to pursue highly unique business models, can participate in the fintech revolution.

The ability of a CDFI to participate in partnerships with online lenders, or to afford the adoption of new financial technology platforms, is at least in part predicated upon that CDFI's production volume, as well as its willingness to adopt some standardized products into their mix of offerings. Online lenders made it clear in our interviews that they cannot invest in building "one-off, idiosyncratic" relationships with large numbers of CDFIs. And even off-the-shelf technology solutions, such as Community Reinvestment Fund's SPARK software, are geared towards CDFIs with at least 100 originations annually. On the other hand, the Association for Enterprise Opportunity (AEO) notes that the TILT Forward Initiative was designed to accommodate even small CDFIs by creating virtual scale and access to product, capital and marketing solutions.

A number of interviewees also cautioned against "go it alone" approaches to platform development. They suggested that the CDFI industry's success is tied to networks of CDFIs entering into partnerships to apply a fintech solution across their markets.

To summarize, CDFIs face a number of important strategic decisions in how to respond to the changing business lending environment. 
These decisions include:

- Whether to embrace greater standardization of loan products-or at least decide to offer a common set of loan products in addition to products that individual CDFIs have designed and are offering alone

- What operational activities CDFIs should outsource versus maintain as a core part of their operations

- To what degree CDFIs should attempt to develop CDFI industry-specific fintech platforms, or conform themselves to existing platforms

- To what degree CDFIs should partner with each other, as opposed to racing to develop their own individualized platforms

- Which elements of the "high touch" practices currently in place at many CDFIs can be retained, and which elements should be replaced with greater automation and standardization

- Whether to accentuate the non-lending roles of CDFIs, such as educating borrowers or engaging in policy advocacy, in response to the growth of online lending 


\section{A Brief Overview of the Online Business Lending Industry}

\section{Small Business Capital Needs in the United States and the Emerging Role of Online Lenders}

Small business lending by banks declined severely during the recession and has not recovered. From 2007 to 2012, small business bank loans plummeted from 13.4 million loans to 5 million loans. During that same time, the percentage of small businesses being awarded loans dropped from 62 percent to 16 percent. $^{2}$ Even as of 2014 , the Wall Street Journal reported that, among the ten largest banks issuing small business loans, volume was down 38 percent from the 2006 peak $(\$ 44.7$ billion versus $\$ 72.5$ billion). ${ }^{3}$ The Federal Reserve 2015 Small Business Credit Survey found that the financing success rate for small businesses improved between Q3 2014 and Q3 2015, but also found that half of firms that had applied for financing reported a financing shortfall, meaning they were not able to raise all of the capital they needed. ${ }^{4}$

Stakeholders that we interviewed for this report (see Table 6) shared the belief that there are significant gaps in small business lending-a problem that both CDFIs and online lenders are trying to address.

You have small businesses that used to be served by the local community bank not getting funding from that local community bank ... there's this massive gap in the market. It is very difficult to measure but we know it is at least $\$ 150$ billion to $\$ 300$ and even greater billion.

- $\mathrm{JH}$, Community Investment Management

There is a significant portion of small business borrowers out there that are just denied by banks or are not given the full amount of credit they seek when applying to banks.

-BM, Fundera

Treasury Secretary Lew named the first problem: 8,000 requests from small businesses for capital or credit are declined every business day. The Micro Capital Task Force sized that gap at $\$ 44$ to $\$ 52$ billion dollar gap, defined as credit amounts of less than $\$ 250,000$. That problem is fundamentally a market failure and as a consequence there are challenges that affect banks, CDFIs,

\footnotetext{
2 Archana Pradhan and Josh Silver. 2014. "Small Business Lending Deserts and Oases." National Community Reinvestment Coalition.

3 Ruth Simon. 2015. "Big Banks Cut Back on Loans to Small Business.” Wall Street Journal, Nov 26, 2015.

4 “2015 Small Business Credit Survey: Report on Employer Firms." Federal Reserve Banks of New York, Atlanta, Boston, Cleveland, Philadelphia, Richmond, St. Louis. March 2016.

https://www.newyorkfed.org/medialibrary/media/smallbusiness/2015/Report-SBCS-2015.pdf.
} 
emerging fintech players and of course, small business owners. It is a classic market failure that requires solving. The second problem is that CDFIs barely scratch the surface of demand for credit from small businesses in low-wealth communities.

- TH, Association for Enterprise Opportunity

All of our small business owners tell us what actually keeps them up at night is their ability to get a loan. We did polling on it. Over 90 percent said that this is something that is deeply concerning to them - the availability of affordable credit.

—CK, Small Business Majority

Online lending is emerging to fill the void left by traditional lenders. According to the Federal Reserve 2015 Small Business Credit Survey, banks are still the most common source to which businesses look for financial small loans. Among firms seeking loans between $\$ 100,000$ and $\$ 1$ million, 52 percent sent in applications to one or more small banks, and 39 percent applied to one or more large banks. However, 22 percent also sent in an application to an online lender. Among businesses seeking loans of less than $\$ 100,000,30$ percent had applied to an online lender. ${ }^{5}$

\section{What is Fintech?}

The Wharton School of Business defines fintech as an economic industry composed of companies that use technology to make financial systems more efficient. ${ }^{6}$ The fintech sector is the subject of substantial investment, with nearly $\$ 23$ billion of venture capital and growth equity deployed to the space from 2010 through $2014 .^{7}$ The term "fintech" covers an industry that is broader than online business lending, the subject of this report.

5 "2015 Small Business Credit Survey: Report on Employer Firms." Federal Reserve Banks of New York, Atlanta, Boston, Cleveland, Philadelphia, Richmond, St. Louis. March 2016.

https://www.newyorkfed.org/medialibrary/media/smallbusiness/2015/Report-SBCS-2015.pdf.

6 Daniel McAuley. 2015. "What is FinTech?" Wharton Fintech. https://medium.com/wharton-

fintech/what-is-fintech-77d3d5a3e677\#.26vz6h97g.

${ }^{7}$ Miklos Dietz et. al. 2015. "Cutting through the noise around financial technology." McKinsey and Company. http://www.mckinsey.com/industries/financial-services/our-insights/cutting-throughthe-noise-around-financial-technology. 
According to a recent McKinsey report, online small business lenders are employing fintech to seek a competitive advantage over mainstream banks in a variety of ways: ${ }^{8}$

- Avoiding physical distribution costs, such as bank branches

- Using data to develop new credit scoring approaches

- Reducing the cost of customer acquisition

- Reducing customer response times

\section{Online Lending Business Models - key marketing "pitch lines"}

\begin{tabular}{|ll|}
\hline Qualify for a line up to $\$ 100,000$ in minutes! & $\underline{\text { Kabbage }}$ \\
Funding in minutes & $\underline{\text { PayPal Working Capital }}$ \\
$\$ 250,000$ in your checking account tomorrow & $\underline{\text { Velocifund }}$ \\
Sign contracts and get your money in as little as 3 days! & $\underline{\text { Dealstruck }}$ \\
Same day approval, next day funding & $\underline{\text { Snapcap }}$ \\
If you use our instant decision application, you'll know immediately whether you qualify. & $\underline{\text { OnDeck }}$ \\
Quickest time to funding-10 minutes & $\underline{\text { Fundera }}$ \\
And our favorite: & $\underline{\text { LendVantage (endorsed by Larry King) }}$ \\
Get pre-approved for up to $\$ 250,000$ in minutes. &
\end{tabular}

In its report Opportunities and Challenges in Online Marketplace Lending, the US Department of the Treasury reviews common elements of the business model for online lenders. ${ }^{9}$ Online business lenders, also referred to as "marketplace" lenders, offer a clear value proposition to their customer: get money fast. These lenders use an online platform whereby a business can apply for credit online, upload information, and receive a quick decision. That loan decision is usually guided by automated underwriting systems that may be pulling data from credit reports but also from nontraditional sources such as real-time business accounting information, payment and sales history, and online small business customer reviews. Online lenders generally

\footnotetext{
8 Miklos Dietz et. al. 2015. "Cutting through the noise around financial technology." McKinsey and Company. http://www.mckinsey.com/industries/financial-services/our-insights/cutting-throughthe-noise-around-financial-technology.

9 Dan Cruz. 2016. “Opportunities and Challenges in Online Marketplace Lending." US Department of the Treasury. https://www.treasury.gov/connect/blog/Pages/Opportunities-and-Challenges-inOnline-Marketplace-Lending.aspx.
} 
do not have a physical presence in the community where the customer goes to meet with a loan officer and apply.

While online lending has its origins in peer-to-peer lending, most marketplace lenders now raise capital from institutional investors. Two primary strategies are employed: a balance sheet model in which the online lender holds the loans in their own portfolio, and a platform strategy in which the online lender will sell loans or issue securities in partnership with a depository institution. In Figures 1 and 2, we present graphics from the US Treasury report that outline these two models:

Figure 1: Direct Lender Model

Figure 1: Direct Lender Model

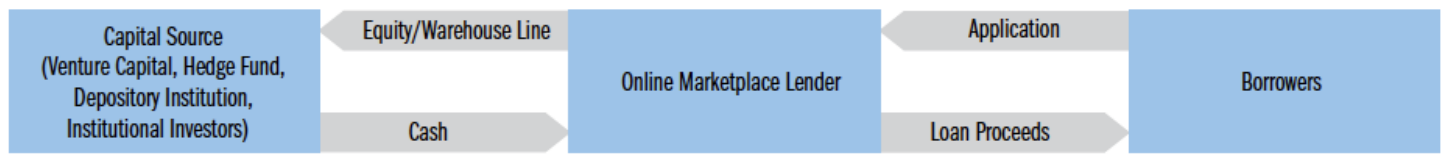

Source: Lending Club, Form 10-K, Flled February 27, 2015.

Figure 2: Platform Lender Model

Figure 2: Platform Lender Model

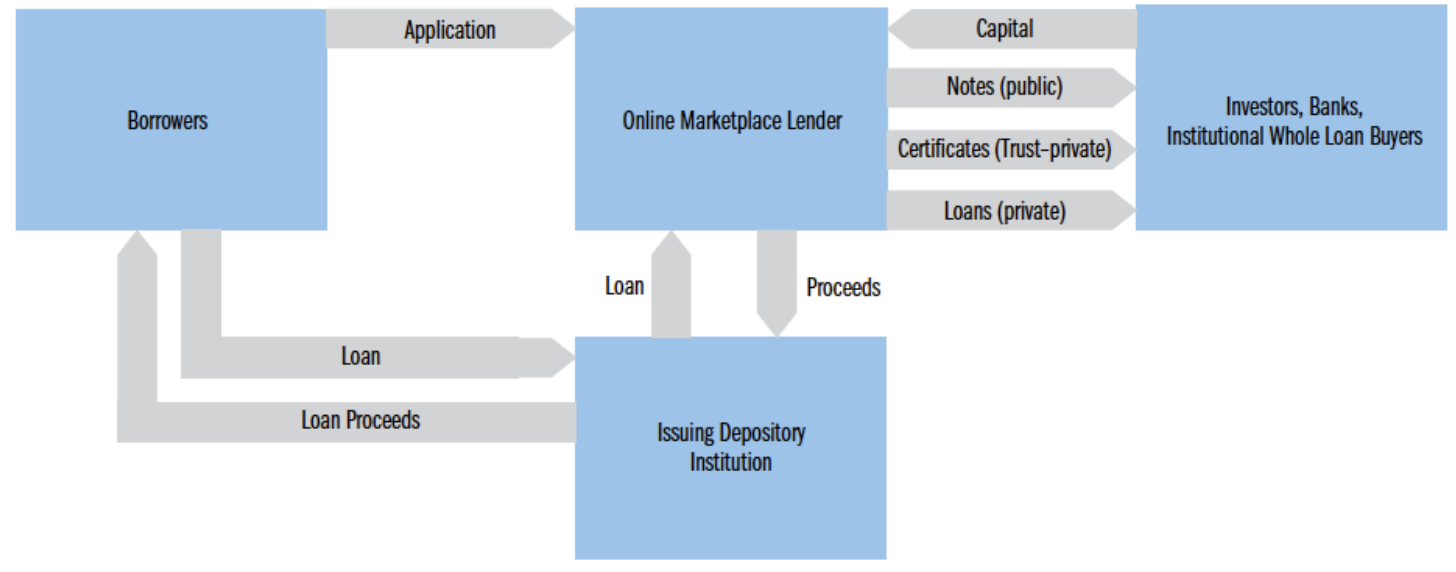

Source: Lending Club, Form 10-K, Filed February 27, 2015.

Key players in the online lending market include:

- Providers of capital

- Loan brokers

- Support services - for example, platform developers or marketing firms

- Local, regional and national banks and credit unions with an online lending presence

- Regulators and potential regulators, including state regulators and the federal Consumer Finance Protection Bureau 
From a regulatory standpoint, online lenders obtain licenses from the states in which they operate. Non-depository online lenders are not subject to federal banking supervision. However, they are subject to federal consumer protection laws and regulation, and the Consumer Finance Protection Bureau is increasing its scrutiny of online lenders (both for business loans and other sectors of marketplace lending). ${ }^{10}$ Bank regulators are also looking at how they might regulate online small business lenders who have partnered with banks. ${ }^{11}$

As a final common element of their business model, online lenders tend to have higher interest rates and shorter terms than mainstream bank financing, and may use linked bank accounts to collect repayment of loans. We look more in depth at loan products offered by marketplace lenders in the next section.

\section{Online Small Business Lending Products}

Per the US Treasury report, online business lenders provide a wide range of products, interest rates, terms, and loan sizes, as seen in Table 1.

Table 1: Loan Products Offered by Online Business Lenders

\begin{tabular}{|c|c|c|c|c|c|c|c|c|}
\hline & & & \multirow[b]{2}{*}{ Product Type } & \multirow[b]{2}{*}{ Rates Range } & \multirow[b]{2}{*}{ Term Range } & \multicolumn{3}{|c|}{ Average Borrower } \\
\hline & & & & & & Loan Size Range & Credit Score & Origination Fees \\
\hline \multirow{9}{*}{ 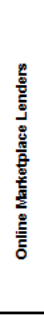 } & $\bar{q}$ & Avant & Term Loan & $9.95 \%-36.00 \%$ APR & $2-5$ Years & $\$ 1,000-\$ 35,000$ & 650 & $0.00 \%$ \\
\hline & $\underline{\underline{z}}$ & Lending Club & Term Loan & $5.99 \%-35.96 \%$ APR & 3-5 Years & Up to $\$ 40,000$ & 699 & $1.00 \%-6.00 \%$ \\
\hline & ¿ & Prosper & Term Loan & $5.99 \%-36.00 \%$ APR & 3-5 Years & $\$ 2,000-\$ 35,000$ & 698 & $1.00 \%-5.00 \%$ \\
\hline & $=\infty$ & Bond Street & Term Loan & $8.00 \%-25.00 \%$ APR & 1-3 Years & $\$ 50,000-\$ 500,000$ & $>640$ & $3.00 \%$ \\
\hline & $\bar{E}$ & Funding Circle & Term Loan & $6.98 \%-32.78 \%$ APR & $1-5$ Years & $\$ 25,000-\$ 500,000$ & $\mathrm{NA}$ & $1.49 \%-4.49 \%$ \\
\hline & $\overline{\boldsymbol{\varphi}}$ & OnDeck & Term Loan & $7.30 \%-98.40 \%$ APR & 3-36 months & $\$ 5,000-\$ 500,000$ & $>500$ & $2.50 \%$ \\
\hline & $\frac{\vec{E}}{0}$ & Common Rond & & $3.50 \%-7.74 \%$ APR fixed/ & & & & \\
\hline & 吾 & D. & Tetion Luain & $2.14 \%-5.94 \%$ APR varulable & 200 yeais & IVIIn. $\$ 5,000$ & NA & $0.00 \%$ \\
\hline & & SoFi & Term Loan & $2.14 \%-5.94 \%$ APR varuiable & $5-20$ years & Min. $\$ 5,000$ & NA & $0.00 \%$ \\
\hline \multirow{6}{*}{ 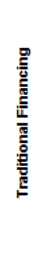 } & 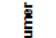 & Bank Loan & Term Loan & $9.66 \%-9.85 \%$ APR & 2 Yearsd & Varies & $\mathrm{NA}$ & Varies \\
\hline & 。ั & Consumer Credit Card & Revolving Line of Credit & $11.98 \%-12.22 \%$ APR & Revolving & Varies & $\mathrm{NA}$ & Varies \\
\hline & 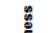 & C\&I Line of Credit & Line of Credit & Fed Funds $L B O R$ + Rate & $\sim 2$ Years & Varies & $\mathrm{NA}$ & Varies \\
\hline & 产 & Commercial Credit Card & Revolving Credcit & Varies & Revolving & Varies & $\mathrm{NA}$ & Varies \\
\hline & 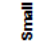 & & & Prime $+2.25 \%$ - Prime + & $\begin{array}{l}\text { Up to } 10 \text { years for } \\
\text { certain uses; Up to } 25\end{array}$ & & & \\
\hline & & SBA 7 (a) Loan & Term Loan & $4.75 \%$ & years for real estate & Up to $\$ 5,000,000$ & $\mathrm{NA}$ & $0.00 \%-3.50 \%$ \\
\hline
\end{tabular}

\footnotetext{
${ }^{10}$ Yuka Hayashi. 2016. "CFPB Increases Scrutiny of Online Lenders.” Wall Street Journal, March 7, 2016.

${ }^{11}$ Rachek Witkowski. 2016. "Bank Regulators Aim at Online Small Business Lending." Wall Street Journal, June 22, 2016.
} 
In its 2015 report The State of Online Small Business Lending, Fundera provided a segmentation of online lenders by product, as well as a description of eligibility and pricing ranges for different products, as shown in Figure 3 and Table 2.

Figure 3: Lender Network by Product

\section{Lender Network By Product}

Short-Term Loan

Medium-Term Loan

SBA Loan

Line of Credit

Invoice Financing

Personal Loan for Business

Equipment Loan

\section{CAN quarterspol OnDeck> DIRECTCAPITAL bizfi}

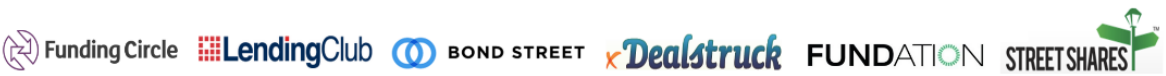

smartbiz

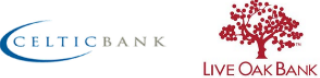

OnDeck> Kabbage $\times$ Dealstruck ${ }_{\text {Credit }}^{\text {me }}$ Junction. QBlueVine fundsox

PROSPER $P$

(2) $\theta$

(6) elease BALBOA

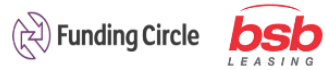

Table 2: Eligibility \& APR Ranges by Loan Product

Eligibility \& APR Ranges by Loan Product

\begin{tabular}{|c|c|c|c|c|c|c|c|c|c|c|c|}
\hline \multicolumn{12}{|l|}{$\begin{array}{l}\text { Short-Term Loans } \\
\text { Medium-Term Loans } \\
\text { Medium-Term LoC } \\
\text { Short-Term LoC } \\
\text { SBA Loans }\end{array}$} \\
\hline $\begin{array}{l}\text { ANNUAL REVENUE } \\
\text { Short-Ter }\end{array}$ & $<100 \mathrm{~K}$ & $100 \mathrm{~K}-200 \mathrm{~K}$ & $200 \mathrm{~K}-300 \mathrm{~K}$ & $300 \mathrm{~K}-400 \mathrm{~K}$ & $400 \mathrm{~K}-500 \mathrm{~K}$ & $500 \mathrm{~K}-600 \mathrm{~K}$ & $600 \mathrm{~K}-700 \mathrm{~K}$ & $700 \mathrm{~K}-800 \mathrm{~K}$ & $800 \mathrm{~K}-900 \mathrm{~K}$ & $900 \mathrm{~K}-1 \mathrm{M}$ & $1 \mathrm{M}+$ \\
\hline $\begin{array}{l}\text { Medium-Term Loans } \\
\text { Medium-Term LoC }\end{array}$ & & & & & & & & & & & \\
\hline $\begin{array}{l}\text { Short-Term LoC } \\
\text { SBA Loans }\end{array}$ & & & & & & & & & & & \\
\hline APR & $5-10$ & $10-15$ & $15-20$ & $20-25$ & $25-30$ & $30-35$ & $35-40$ & $40-45$ & $45-50$ & $50+$ & \\
\hline Short-Term Loans & & & & & & & & & & & \\
\hline $\begin{array}{l}\text { Medium-Term Loans } \\
\text { Medium-Term LoC }\end{array}$ & & & & & & & & & & & \\
\hline $\begin{array}{l}\text { Short-Term LoC } \\
\text { SBA Loans }\end{array}$ & & & & & & & & & & & \\
\hline
\end{tabular}


FitSmallBusiness.com provides a comparison in their article, Kabbage vs. OnDeck Capital vs. PayPal - Who Offers the Best Short-Term Loans for Small Businesses? (see Table 3). ${ }^{12}$

Table 3: Comparison of Small Business Short-Term Loans

\begin{tabular}{|l|c|c|c|c|}
\hline & Kabbage & OnDeck Capital & PayPal Working Capital & Merchant Cash Advance (generic) \\
\hline maximum amount that they lend & $\$ 2,000-\$ 100,000$ & $\$ 5,000-\$ 500,000$ & $\$ 1,000-\$ 85,000$ & $\$ 5,000-\$ 150,000$ \\
\hline terms & $1-12$ months & 3 to 36 months & $\begin{array}{c}\text { No fixed maturity date, but } \\
\text { typically takes } 1-18 \text { months }\end{array}$ & $3-12$ months \\
\hline expected APR range & $40-80 \%$ & $40-80 \%$ & $15-30 \%$ & Over $100 \%$. \\
\hline approval time & Same Day & Same Day & Same Day & No Minimum \\
\hline minimum credit score & 550 & 500 & No Minimum & $12 \%$ of annual revenues \\
\hline how much will they lend? & Varies & $15 \%$ of annual revenues & $4-15 \%$ of annual PayPal revenues & No \\
\hline personal guarantee needed? & No & Yes & \multicolumn{2}{|c|}{ No } \\
\hline
\end{tabular}

\section{Industry Growth Trends and Scale}

Overall, online lending is growing fast and is seen as having tremendous growth potential. The Treasury report cites research identifying a $\$ 1.0$ trillion addressable market for online marketplace lenders, and estimating that loan origination volumes could reach $\$ 90$ billion by 2020 . Consumer unsecured credit represents the largest sector within the industry. However, small business online lenders are also growing substantially and are operating at a scale that dwarfs the CDFI industry:

- OnDeck, one of the largest online small business lenders, saw its originations grow to $\$ 1.9$ billion in 2015, more than triple its 2013 volume.

- Lending Club, which offers both personal loans and business loans, lent out $\$ 3.5$ billion in just the first two quarters of 2016; during 2015 it originated $\$ 8.4$ billion.

- PayPal working capital originates $\$ 1$ billion per year in merchant advance lending.

That said, banks remain the largest business lenders in the United States. Total nonbank lending in 2014 was $\$ 190$ billion, compared to $\$ 350$ billion in small business loans made by the banking industry. ${ }^{13}$ There are also threats to the continued growth of fintech lenders. Notably, shares in OnDeck, Lending Club, and

\footnotetext{
12 Priyanka Prakash. 2016. "Kabbage vs. OnDeck Capital vs. PayPal - Who Offers the Best Short-Term Loans for Small Businesses?" FitSmallBusiness.com http://fitsmallbusiness.com/kabbage-vs-ondeck-captial-vs-paypal/.

${ }^{13}$ Julapa Jagtiani and Catharine Lemieux. 2016. "Small Business Lending: Challenges and Opportunities for Community Banks." Philadelphia Federal Reserve. http://fic.wharton.upenn.edu/fic/papers/16/16-02.pdf.
} 
other online lenders dropped this spring as OnDeck reported a $\$ 12.6$ million loss, in part due to problems selling loans to investors. ${ }^{14}$

On the other hand, CDFI Fund statistics suggest that the entire combined CDFI industry is a tiny player compared to online lenders. The most recent CDFI Fund statistics are for 2014, and only those CDFIs that have received awards from the Fund in recent years are required to report. All reporting CDFIs indicated making $\$ 685$ million in business loans in $2014 .{ }^{15}$ This disparity is also seen when looking at the number of loans made. OnDeck, for example, made 37,141 loans in 2015, compared to 4,078 for all reporting CDFIs in 2014.

\section{Portfolio Performance}

Paypal Working Capital's 2015 annual report indicated a 90+ day delinquency rate of 4 percent (see Table 4), which would generally be considered acceptable in the CDFI industry. (The CDFI Fund Minimum Prudent Standard for 90+ day delinquencies is 10 percent.)

Table 4: PayPal Working Capital Loan Distribution by FICO Score

\begin{tabular}{|l|l|l|}
\hline PayPal Working Capital 16 & 2015 & 2014 \\
\hline \% loans FICO > 680 & $54 \%$ & $54 \%$ \\
\hline \% loans FICO score $<599$ & $9 \%$ & $9 \%$ \\
\hline \% loans $>$ 90 days outstanding & $4 \%$ & $4 \%$ \\
\hline
\end{tabular}

Table 5 is from 2015 PayPal's 10-K statement.

Table 5: 2015 PayPal Working Capital (in millions)

\begin{tabular}{|l|l|l|l|l|l|l|}
\hline $\begin{array}{l}\text { Within } \\
\text { Original }\end{array}$ & $\begin{array}{l}30-59 \text { Days } \\
\text { Greater }\end{array}$ & $\begin{array}{l}60-89 \text { Days } \\
\text { Greater }\end{array}$ & $\begin{array}{l}\text { 90-180 } \\
\text { Days } \\
\text { Greater }\end{array}$ & $\begin{array}{l}\text { 180+ Days } \\
\text { with } \\
\text { Minimum } \\
\text { Payment in } \\
\text { Last } 90 \\
\text { Days }\end{array}$ & $\begin{array}{l}\text { Total Past } \\
\text { Original } \\
\text { Expected } \\
\text { Repayment }\end{array}$ & $\begin{array}{l}\text { Total } \\
\text { Merchant } \\
\text { Receivables }\end{array}$ \\
\hline$\$ 326$ & $\$ 47$ & $\$ 21$ & $\$ 24$ & $\$ 3$ & $\$ 95$ & $\$ 421$ \\
\hline
\end{tabular}

${ }^{14}$ Stephen Gandel. 2016. "Why Shares of Fintech Lenders OnDeck and Lending Club Are Getting Crushed." Fortune Magazine. http://fortune.com/2016/05/03/ondeck-lendingclub-shares/.

${ }^{15}$ Analysis of FY 2014 CDFI Fund CIIS Data Release.

16 PayPal. 2016. "Form 10-K." https://investor.paypal-corp.com/secfiling.cfm?filingid=1633917-16$\underline{113 \& \mathrm{cik}=1633917 .}$. 
OnDeck reported a 15+ day delinquency rate of 5.3 percent for the second quarter of 2016, down from 8.0 percent for Q2 2015. ${ }^{17}$

Recent media articles nonetheless report growing investor concern over the credit quality of online loans, including concerns over:

- Unintentional "stacking" of loans from multiple lenders to the same borrower due to loose credit checking and credit reporting procedures ${ }^{18}$

- Sales of loans not meeting investor requirements ${ }^{19}$

\section{Consumer Concerns}

Regulators, CDFIs, and customers of online lenders have all expressed concerns about whether some online loans take advantage of customers who need money quickly, and find themselves in over their heads.

According to the 2015 Small Business Credit Survey: Employer Firm Report, ${ }^{20}$ small businesses were generally dissatisfied with terms of online lenders.

Overall, 20\% of employer firms applied at an online lender. While the approval rate was relatively high for applicants ( $71 \%$ were approved for at least some credit), approved firms were not very satisfied with their experience. The satisfaction score was just 15-far below that of small and large banks. Dissatisfied firms reported concerns with high interest rates and unfavorable repayment terms.

Several of the CDFIs we interviewed related stories of online borrowers who have gotten into trouble, and their organization's efforts to help these borrowers.

So he goes online and he gets a loan in 24 hours. And it solves his immediate problem and it's a debt trap. And he was lucky enough. He met Accion Chicago and they got him out of it. He had never heard of a CDFI before that. A CDFI bailed him out. I think that's a great business for a CDFI-bailing people out. - CK, Small Business Majority

We are competing with online lenders, and their borrowers in turn come to us after they get in trouble and realize that they can't possibly cover the loan payments 98 percent of the time ... I'd say 15 percent [of our customers come as a result of online loan troubles]. But it's a lot. We often decline them. They're in too deep. And unfortunately, some of them I never hear from again. -CP, Pacific Community Ventures

\footnotetext{
17 OnDeck. 2016. “OnDeck Reports Second Quarter 2016 Financial Results.” https://investors.ondeck.com/press-and-events/press-releases/press-releasedetails/2016/OnDeck-Reports-Second-Quarter-2016-Financial-Results/default.aspx. ${ }^{18}$ Reuters. 2016. "This is the Latest Threat to Online Lenders." June 10, 2016. ${ }^{19}$ James Rufus Koren. 2016. "As trouble piles up, online lenders pull back." May 9, 2016. 20 "2015 Small Business Credit Survey: Report on Employer Firms." Federal Reserve Banks of New York, Atlanta, Boston, Cleveland, Philadelphia, Richmond, St. Louis. March 2016. https://www.newyorkfed.org/medialibrary/media/smallbusiness/2015/Report-SBCS-2015.pdf.
} 
What they're feeding these small business owners is crack cocaine, for lack of a better analogy, because they get an immediate satisfaction and then they put them in a place where the small business immediately has to come back for another loan just to cover the costs and overhead for what the first one was. -JE, Coastal Enterprises Inc.

There is a lot to learn from online lending but many of the online lenders have chosen to go about their business with a short-term perspective, which is where you get a lot of the predatory practices and also the bad reputations of online lending in many ways.

- JH, Community Investment Management

Federal regulators have expressed that they are aware of these issues and the Consumer Finance Protection Bureau has invited consumers to report complaints about online lenders. ${ }^{21}$

\section{A Brief Overview of CDFIs and Their Role in Business Lending}

\section{What is a CDFI?}

Opportunity Finance Network, a membership network of CDFIs, describes CDFIs on its website:

CDFIs are private financial institutions that are 100\% dedicated to delivering responsible, affordable lending to help disinvested people and communities join the economic mainstream.

As mission-driven lenders, CDFIs leverage funding from private and public sources to finance community businesses - including small businesses, microenterprises, nonprofit organizations, commercial real estate, and affordable housing - and spark job growth and retention in hard-to-serve U.S. markets.

In addition to connecting capital to communities and people that need it, many CDFIs also provide financial education, technical assistance, and capacitybuilding support to the organizations, businesses, or individuals they serve. ${ }^{22}$

\footnotetext{
21 Consumer Financial Protection Bureau. 2016. "CFPB Now Accepting Complaints on Consumer Loans from Online Marketplace Lender.” http://www.consumerfinance.gov/aboutus/newsroom/cfpb-now-accepting-complaints-on-consumer-loans-from-online-marketplacelender/.

22 Opportunity Finance Network. "What are CDFIs?" http://ofn.org/CDFIs.
} 
CDFIs are certified by the US Department of the Treasury. ${ }^{23}$ As of May 2016, there were 1,013 certified CDFIs, including:

- 530 nonprofit loan funds

- 122 banks or thrifts

- 276 credit unions

- 70 depository institution holding companies

- 15 venture capital funds

\section{CDFI Impacts in Small Business Lending}

Not all CDFIs engage in small business lending. CDFIs may focus instead on lending for affordable housing, commercial real estate, consumer finance, community facilities, or a combination of lending across multiple sectors.

An impact evaluation of the CDFI industry prepared by the Carsey School of Public Policy in 2014 had several findings related to the business-lending activities of CDFIs: ${ }^{24}$

- CDFIs that were required to report lending activity to the US Treasury CDFI Fund - a subset of the industry, determined by whether the CDFI had recently received financial support from the Fund-reported making $\$ 2.04$ billion in business loans between 2003 and 2012 .

- The CDFI industry has grown substantially, leveraging investment and increasing its lending activity even in the face of a recession and cataclysmic changes in the financial environment. However, the CDFI sector remains tiny relative to mainstream financial institutions. For example, Community Reinvestment Act (CRA)-reported small business lending in 2012 was 464 times the business-lending volume reported by CDFIs to the CDFI Fund.

- CDFIs are delivering 65 percent of their business lending volume to borrowers from targeted, historically underserved groups such as low-income or minority borrowers, borrowers who were rejected by a bank or credit union, or borrowers located in a CDFI Fund designated Investment Area.

\footnotetext{
${ }^{23}$ Information about CDFI certification, as well as the most recent list of certified CDFIs, can be accessed on the CDFI Fund website: https://www.cdfifund.gov/programstraining/certification/cdfi/Pages/default.aspx.

${ }^{24}$ Michael Swack, Eric Hangen and Jack Northrup. 2014. "CDFIs Stepping into the Breach: An Impact Evaluation." The Carsey School of Public Policy. https://www.cdfifund.gov/Documents/CDFIs\%20Stepping\%20into\%20the\%20Breach\%20Impact \%20Evaluation\%20Report.pdf.
} 
- CDFI business loans are about twice as likely as CRA small business loans to be located in high-poverty census tracts (49 percent versus 24 percent by dollar volume).

- CDFIs are meeting needs for financing with "plain vanilla" products that minimize risks to the borrower. Most financing offered by CDFIs is on terms that decrease borrower risks. However, many CDFIs appear to struggle to meet market needs for longer-term loans, a dynamic that may relate to the lack of access to long-term capital in the sector.

Opportunity Finance Network (OFN) has compiled impact data for its member organizations - a subset of the overall CDFI industry, and one that is selected in part based on organizational performance. From 1985 to 2014, OFN member CDFIs have reported: 25

- Investing $\$ 42$ billion in loans nationwide (across all loan types)

- Creating or maintaining 934,000 jobs

- Financing 143,000 businesses and microenterprises

- Serving a diverse customer base that is 48 percent people of color, 73 percent low-income borrowers, and 48 percent women borrowers, as well as 27 percent rural

These accomplishments are impressive, but are small relative to the size of the small business credit needs in the US. The Association for Enterprise Opportunity notes that the 143,000 businesses financed by OFN members-cumulatively over almost 30 years - compares to 2.2 million small businesses in low-wealth communities who seek credit in a typical, single year.

\section{Issues of Scale and Operating Efficiency in the CDFI Industry}

As noted in the section above, CDFIs serve a tiny fraction of the overall businesslending market; the same observation holds true for other sectors such as mortgage and consumer financing.

While online lenders are relatively new entrants into the business-lending marketplace, they are already vastly out-producing the CDFI industry. Leading online lenders are now originating billions of dollars in loan volume per year-for example, during 2015, LendingClub made $\$ 11$ billion (which includes both small business and consumer lending) and OnDeck made $\$ 1.6$ billion in loans. CDFI Fund statistics suggest that the entire combined CDFI industry would be a small player next to these lenders. The most recent CDFI Fund statistics are for 2014, and only CDFIs that have received awards from the Fund in recent years are required to report. All reporting

\footnotetext{
${ }^{25}$ Opportunity Finance Network. 2015. "CDFIs Provide Opportunity. For All." http://ofn.soscale.com:8080/sites/default/files/OFN_Infographic 2014_Letter_Printable_0.pdf.
} 
CDFIs indicated making $\$ 685$ million in business loans in $2014 .{ }^{26}$ This disparity is also seen when looking at the number of loans made. OnDeck, for example, made 37,141 loans in 2015, compared to 4,078 for all reporting CDFIs in 2014.

Individual CDFIs, even leading ones, have very small loan volumes compared to online lenders, although it should be kept in mind that most lend within a specific region of the country. For example, according to data from financial audits, Opportunity Fund lent $\$ 37$ million in 2015, Coastal Enterprises $\$ 20.6$ million, and Craft3 $\$ 77.4$ million. Small CDFIs may originate less than $\$ 1$ million in business loans in a given year.

One of the main issues impacting the CDFI industry's ability to lend at scale is its lack of access to capital. CDFIs have been dependent largely on government grants and CRA-motivated bank investment to capitalize their loan portfolio. ${ }^{27} \mathrm{~A}$ number of factors have affected CDFIs' ability to access broader capital markets, including a lack of standardization of loan products, the absence of tradeable markets and liquidity for CDFI loan assets, and difficulties in benchmarking CDFI investment performance on risk and return. ${ }^{28}$ The Carsey School industry analysis of the CDFI field in 2012 found that operating efficiencies were a driving factor impacting CDFI financial performance for many CDFIs, especially those with smaller asset bases. ${ }^{29}$

\section{Recent CDFI Efforts to Work with Fintech in Business Lending}

In this section, we report on a number of efforts that CDFIs have undertaken to work with the fintech revolution - seeking to apply new technology and/or new partnerships to their business models, as well as seeking to adapt their role as educators and technical assistance providers to the new environment. This section should be treated as a sampling of efforts around the industry and not an exhaustive inventory.

\footnotetext{
${ }^{26}$ Carsey School of Public Policy analysis of FY 2014 CDFI Fund CIIS Data Release.

${ }^{27}$ Jeremy Nowak. 2016. "CDFI Futures: An Industry at a Crossroads." Opportunity Finance Network. http://ofn.org/sites/default/files/resources/PDFs/Publications/NowakPaper FINAL.pdf.

${ }^{28}$ Michael Swack and Eric Hangen. 2015. "Scaling US Community Investing: The Investor-Product Interface." Global Impact Investing Network.

https://thegiin.org/assets/images/pub/GIIN_Scaling\%20US\%20Community\%20Investing\%20The \%20Investor-Product\%20Interface.pdf.

${ }^{29}$ Michael Swack, Jack Northrup and Eric Hangen. 2012. "CDFI Industry Analysis Summary Report." The Carsey Institute. https://www.cdfifund.gov/Documents/Carsey\%20Report\%20PR\%20042512.pdf.
} 


\section{Opportunity Fund / Lending Club Partnership}

In 2015, Opportunity Fund announced a partnership with Lending Club to provide $\$ 10$ million in loans to 400 small businesses in underserved areas of California. ${ }^{30}$ The then-CEO of Lending Club, Renaud Laplanche, described Lending Club's goal as making their "technology available to Opportunity Fund to help them scale further, to meet the needs of a greater number of small business owners." The partnership generates a market channel for Opportunity Fund to serve borrowers who have been denied by Lending Club. The Opportunity Fund website describes the process as follows:

Borrowers apply for a loan through Lending Club, and after Lending Club collects the initial application and performs its automated screening, Opportunity Fund will review the applicants. Opportunity Fund will fund qualifying applicants that otherwise would have been turned down. Opportunity Fund will then service the loans, offering business advice and support to help these businesses succeed.

Opportunity Fund CEO Eric Weaver described their strategy in our interview with him:

We looked at a partnership model. Was there a way that we could get fintech companies to do something we could never get banks to do, which is to do an automated referral to us of turned down clients?

We knew that if somebody went online looking for a loan through a Lending Club and were referred to a CDFI that then took two months to make up its mind, then they would never stick around. They would be with OnDeck or Can Capital or somebody else. So we knew that we had to create the kind of speed and efficiency and customer service that Lending Club provides and we've built that capability ... we spent several months just upping our game technologywise.

The partnership is still in early phases and Weaver reports that they are "just learning what we're doing." Opportunity Fund has done about 25 loans for approximately a half-million dollars in volume through this channel so far, compared to about 2,500 loans a year overall. One factor that may be impacting production is that Lending Club's overall loan volume dropped off during 2016, and according to Weaver, the organization stopped advertising small business lending for a time, in the wake of the resignation of its CEO.

\footnotetext{
${ }^{30}$ Eric Weaver. 2015. "Opportunity Fund partnering with Lending Club, President Clinton announces." Opportunity Fund. http://www.opportunityfund.org/media/blog/clinton-announces-partnershipbetween-opportunity-fund-and-lending-club.
} 


\section{TILT Forward-AEO}

TILT Forward is a national initiative of AEO to develop and launch technology-led product, capital and marketing solutions for mission-focused lending. The TILT Forward Initiative is building new industry infrastructure to support lower cost product and service distribution, as well as to promote innovation.

The initiative includes three interdependent components:

- Project CUE

- DreamFund

- The TILT Forward Network

Project CUE connects applicants that banks and nonbank lenders can't serve to responsible financing and trusted guidance. For bank users, it presents a turnkey, scalable referral program. For CDFIs, it is a source of qualified leads. For business owners, it reduces search costs to find CDFIs.

Seed funding for the Project CUE solution came from the CDFI Fund when this proposal was selected as the winner of the 2015 Innovation Challenge. The platform launched with an initial cohort of CDFIs and the first two committed referral partners, Woodforest National Bank and OnDeck. Each are referring applicants they cannot serve to CDFIs through the Project CUE solution at no cost to CDFIs.

DreamFund was launched in mid-2015 to demonstrate proof of concept for a shared CDFI balance sheet and the use of common products. DreamFund serves two primary functions, it licenses products from third parties making them available to CDFIs and it aggregates capital.

DreamFund enables the capitalization of licensed products for CDFIs that are capital constrained, or permits subscale CDFIs access to best of breed fintech platforms using their own funds.

The TILT Forward Network is designed to accelerate identification and adoption of critical innovations in the way that small businesses and aspiring entrepreneurs in low-wealth communities access capital and guidance on the path to capital. The network serves as a mechanism to share knowledge and test innovations. (Think of it as a "skunk works.") The network formally launched in 2016 with 13 inaugural CDFIs and has since grown to include 16 CDFIs and a growing set of nonprofit service providers.

AEO and the TILT Forward Initiative rely on cross-sector collaboration to better meet the needs of Main Street entrepreneurs. One example of effective crosssectoral collaboration is AEO's long-standing partnership with OnDeck. OnDeck has supported the TILT Forward Initiative in several ways:

- Sending referrals to CDFIs through Project CUE 
- Providing its technology expertise to inform the design of the Project CUE solution

- Licensing its data analytics and loan process automation platform to DreamFund without royalty as the first loan product offered by DreamFund

The collaboration between AEO and OnDeck has evolved over time to reflect lessons learned and will continue to evolve. Daniel Gorfine, Vice President of External Affairs at OnDeck, described the initiative in our interview with him:

The concept behind AEO and the original TILT Forward Initiative was that if we could create a shared platform or almost a common utility through the AEO, that any interested or participating CDFI could plug into by adopting that set of standards, that common platform, that common approach, you would be able to onboard and incorporate far more CDFIs far more efficiently than you would be able to ifyou were trying to, again, navigate that on an idiosyncratic one-off basis.

The idea of doing this through a common platform for CDFIs makes so much more sense from an efficiency perspective because ... the key benefit of the model is that it is creating increasing standardization and efficiency. You're going to lose that when you start doing a lot of one-offs. You lack the benefit of a scalable platform.

From a CDFI point of view, TILT Forward seeks to add value by helping them to expand their product portfolio, offer proven products at lower cost, and bring down overhead costs, while retaining control over client relationships. ${ }^{31}$

The TILT Forward Initiative includes several sources of value for CDFIs and small business owners:

\section{- Virtual scale}

Each component of the TILT Forward Initiative makes it possible for small and often resource-constrained organizations to access qualified leads, offer products and services that they would not otherwise be able to access by centralizing due diligence and aggregating client volume nationally. This is attractive for product partners and informs the design of new products, services and delivery models.

\footnotetext{
31 TILT Forward. "How does TFI add value for your nonprofit?" http://www.tiltforward.com/nonprofits/.
} 
- More “yes!"

Referrals to CDFIs directly from banks and nonbank lenders increase odds of success for a business owner. At the same time, access to additional products enables organizations to better serve the businesses in their communities.

\section{- Cost savings to borrowers}

DreamFund users are able to offer licensed products at subsidized rates. To date, CDFIs offering the working capital loan licensed from OnDeck have saved borrowers an average of $\$ 2,750$ per loan. These borrowers tend to be smaller and higher risk than OnDeck's average borrowers.

There is no cost to CDFIs for participating in the TILT Forward Initiative beyond annual membership dues to AEO. At present, there is also no cost to use Project CUE for lead generation. Access to the OnDeck product through DreamFund has no cost for use and a 2 percent origination fee on closed loans to DreamFund and AEO. (OnDeck has contributed their platform to CDFIs for free.)

Tammy Halevy of the Association for Enterprise Opportunity describes the need for the TILT Forward Initiative:

The TILT Forward Initiative was developed in response to early insights AEO developed through research, member engagement and our policy and advocacy work. Specifically, TILT Forward is AEOs response to the $\$ 52$ billion dollar credit gap on Main Street and the gap between the needs of the estimated 2.2 million small business owners in low-wealth communities that seek credit in a given year compared to the current capacity of mission-focused lenders and business service providers to serve that demand. We will continue to focus on innovative solutions to better enable CDFIs to meet the needs of underserved small business owners in their communities.

\section{CRF SPARK}

The Community Reinvestment Fund (CRF) has developed SPARK, a loan origination software package for small business lenders, in partnership with the National Federation of Community Development Credit Unions. SPARK helps credit unions and other business lenders to originate loans, including Small Business Administration (SBA) loans between $\$ 25,000$ and $\$ 5,000,000$, facilitating the origination process from application to closing for both the lender and the borrower. ${ }^{32}$ A key differentiating feature of the software is that it focuses on the

\footnotetext{
32 Spark Team. 2016. "Community Reinvestment Fund, USA and National Federation of Community Development Credit Unions Partner on a Business Lending Solution." Spark. http://www.lendwithspark.com/community-reinvestment-fund-usa-and-national-federation-ofcommunity-development-credit-unions-partner-on-a-business-lending-solution/.
} 
borrower as well as the lender, and offers a borrower-facing interface. The software also includes a web-based pre-qualification plug-in to help generate leads online.

Frank Altman, Executive Director of CRF, described some of CRF's philosophy behind the rollout of SPARK in our interview with him:

I have a hard time with the term "collaboration" ... I think value exchange is the way we need to go. It's identifying what the value is and is there enough value there that someone is willing to pay for it.

Keith Rachey, CRF's Chief Operations Officer, added:

We are looking at holistic solutions for the industry of which we see technology as an enabler to make that happen ... our ultimate goal is to expand the visibility of not just the CDFIs that are on SPARK, but the industry as a whole.

According to Nick Elders, CRF's Vice President of Technology Services and Solutions, SPARK is intended to help CDFIs who already have significant business-lending volume to grow to scale:

It really comes down to a number of units perspective. If you're doing 20 or 30 loans a year, [CRF SPARK] might not be the best fit both financially and sophistication wise. Now if you're doing 100 loans a year and have plans to make that 300 loans a year, 2 or 3 years from now, and you know that you are going to have to leverage technology to get there, then [CRF SPARK is] a great fit for that.

There are currently eight organizations leveraging the SPARK platform. It has facilitated roughly $\$ 317$ million in loan volume spread over 500 loan units.

\section{Mirador}

Mirador is a fintech company that has worked with CDFIs and mission lenders to help them optimize their small business loan origination process. Its platform includes capabilities such as a pre-qualification filter, online borrower application, automated document collection, and predictive machine learning algorithms for enhanced risk assessment, among other features. ${ }^{33}$ Bill Ervin, Senior Vice President for Business Development, described Mirador in our interview with him:

We are strictly a technology company. We are not a direct lender. We have a couple of CDFIs on our platform today-Excelsior Growth Fund out of New York and CDC out of San Diego that are two of our better customers. They've been using our platform in a number of different ways.

\footnotetext{
${ }^{33}$ Mirador. "Lending platform capabilities.” https://www.miradortech.com/capabilities.
} 
As Ervin explained, Mirador sees the potential for working with more CDFIs:

We'd love to add a lot more CDFIs and banks and credit unions and that's what we're trying to do. We're trying to build out what I am calling is a national CDFI network. I am looking at having maybe 20 of the top CDFIs in the country that will be able to be on a platform and use it for all their borrowers just like they do every day, but at the same time also be tied into the network piece of declines in their markets where they are licensed and really keep everything inside our own network without letting anything back out. These 20 [CDFIs] that I am talking about banding together and forming a network is much more powerful than doing it on their own and trying to compete against the other banks out there that are much larger with much deeper pockets. We've begun to interact with the top four banks in the country and they would like to send more of their business, more of their declines to the CDFIs rather than sending them on to the alternative lenders.

To date, two CDFIs are on the Mirador platform.

\section{Pathway Lending}

Pathway Lending, a CDFI based in Nashville, Tennessee reports that it is developing a new, customer-facing website that will take online loan applications and integrate with its SalesForce CRM software. Clinton Gwin, President of Pathway Lending, describes the process:

When somebody goes online, they'll put in the exact [same] 13 characteristics that they put in for a Lending Club loan and while we're not going to decision this right there on the spot, we're going to tell them whether or not they qualify for expedited underwriting and can have a three day turn. It's what we're hoping for.

Gwin further indicated that these fast approvals would be for applicants with strong credit-a 1 or 2 on a scale of 1 to 9. Gwin emphasized that Pathway has been paying careful attention to measuring the time from taking a completed application to fund a loan, using SalesForce to provide that metric. In the past, Pathway had been taking 75 days, and has now gotten down to 21 days. Gwin commented on the importance of fast turnaround for Pathway's customers, which has motivated Pathway to invest in this new technology:

We knew we had to get to where our customers were. They need money in 10 to 15 , maybe 20 days after an application. They don't need it in 75 days. They're not buying a building. They're buying payroll relief. 


\section{OFN Venturize}

Venturize is an educational website launched by Opportunity Finance Network, partly in response to the growth of online marketplace lending, to help small business owners understand their options and find the best loan product for their business. ${ }^{34}$

The site includes an interface where potential borrowers can describe their borrowing needs, credit score, and length of time in business, and see a presentation of the types of loans that would be available to them. It also includes other tools, such as a checklist to prepare for borrowing and a list of questions to consider when evaluating loan options. The website does not connect or refer borrowers to specific loan products or lenders.

\section{Observations from Industry Stakeholders on Opportunities and Challenges for Business Lending CDFls}

The Center for Impact Finance conducted in-depth interviews with 25 stakeholders, including CDFI leaders and representatives of the fintech and online business lending industry. The interviewees are listed in Table 6.

Table 6: CDFI Leaders Interviewed

\begin{tabular}{|l|l|}
\hline Initials & Name, Title, and Company \\
\hline AZ & Adam Zimmerman, President and CEO, Craft3 \\
\hline AK & Ami Kassar, Multifunding \\
\hline BE & Bill Ervin, SVP Business Development, Mirador Lending, Inc. \\
\hline BM & Brayden McCarthy, Fundera \\
\hline CE & Connie Evans, CEO, Association for Enterprise Opportunity \\
\hline CP & Carly Perera, Associate Director of Lending, Pacific Community Ventures \\
\hline CGO & Catherine Godschalk, Vice President, Calvert Foundation \\
\hline CG & Clinton B. Gwin, President, Pathway Lending \\
\hline CK & Conan Knoll, Small Business Majority \\
\hline DG & Daniel Gorfine, On Deck \\
\hline DH & Don Harrington, Vice President, Chief Credit Officer, The Support Center \\
\hline EW & Eric Weaver, CEO, Opportunity Fund \\
\hline FA & Frank Altman, CEO, Community Reinvestment Fund \\
\hline HH & Hank Helton, Senior Vice President, Pathway Lending \\
\hline JH & Jacob Haar, Community Investment Management \\
\hline JS & Jennifer Sporzynski, Senior Program Director, Coastal Enterprises, Inc. \\
\hline JE & John Egan, Senior Vice President for Investments, Coastal Enterprises, Inc. \\
\hline KC & Kurt Chilcott, President \& CEO, CDC Small Business Finance \\
\hline
\end{tabular}

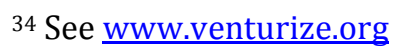




\begin{tabular}{|l|l|}
\hline Initials & Name, Title, and Company \\
\hline KH & Kate Hao, CEO, Happy Mango \\
\hline KR & $\begin{array}{l}\text { Keith Rachey, Senior Vice President \& Chief Operations Officer, Community } \\
\text { Reinvestment Fund }\end{array}$ \\
\hline LCP & Louis Caditz-Peck, Special Initiatives, Lending Club \\
\hline NE & $\begin{array}{l}\text { Nick Elders, Vice President of Technology Services and Solutions, Community } \\
\text { Reinvestment Fund }\end{array}$ \\
\hline NK & Najada Kumbuli, Officer, Strategic Initiatives, Calvert Foundation \\
\hline RM & Ray Moncreif, COO, Kentucky Highlands Investment Corporation \\
\hline TH & Tammy Halevy, SVP, New Initiatives, Association for Enterprise Opportunity \\
\hline
\end{tabular}

\section{Key Themes Emerging from Stakeholder Interviews}

\section{CDFI stakeholders recognize that, to date, their industry has had limited impact in addressing small business credit needs.}

There are 2.2 million small businesses that are located in eligible CDFI geographies that are active in the credit market in a given year. And today, if I am super generous, CDFIs reach 2 percent of that addressable market. - TH, Association for Enterprise Opportunity

We're the largest, we've been the most prolific Community Advantage lender and the volume that we're doing, last year... we funded 90 loans or something like that. It not even in the order of magnitude of what online lending is doing. -KC, CDC Small Business Finance

If you look at the 900 plus licensed CDFIs, there's only a miniscule percent that does business financing. The vast majority does housing or business real estate. They don't have any idea how to finance accounts receivable. They don't have any idea how to finance inventory. They do the easy stuff. They do the low hanging fruit because no one wants to take the risk. No one wants to do the hard work. They want to sit in their nice little offices and they want to do the easy stuff.

- RM, Kentucky Highlands Investment Corporation

In terms of scaled access, I don't think [CDFIs have] moved the needle to the extent that the online lending movement and online lending has the potential for.

-BM, Fundera 


\section{Online lenders are reaching customers due to their accessibility to the customer-which raises the question of how CDFIs could become more accessible themselves.}

They've gone to the bank and they've been turned down. They don't know where to go next. They haven't heard of a CDFI. They know a SBA loan is going to take forever. And they start googling small business.

- CK, Small Business Majority

A guy sits around in his underwear in his garage at night thinking with a Budweiser-he needs to make payroll on Friday and it's Wednesday.

- $\mathrm{HH}$, Pathway Lending

Here is a class of business owners that are in desperate need of capital to grow their business, and they're enticed with very fast turnaround, low application bar, and really fast decisioning - and that is all three of those things that are the antithesis of what typical CDFIs, at least historically, have had as a front door experience."

-JE, Coastal Enterprises

People who are small business owners who are 40 or younger, they do everything online and they do it in the evening. They don't take away working hours and spend time on this. They don't even use their computers. They use their phones. So the question is: will CDFIs be able to compete with online lenders, will they partner with online lenders and stay relevant or will they be OK just focusing on their niche specialty market where others are not interested in their borrowers? But the market is getting narrower and narrower.

- $\mathrm{JH}$, Community Investment Management

[CDFIs] don't have a strong understanding of the small business borrower. -KC, CDC Small Business Finance

What I think [CDFIs] have learned is that our customers are online and we should offer that. We should have a way for our customers to interact with us online, which we do.

- CP, Pacific Community Ventures

I think the CDFI industry for a long time had tried to sell, and we're still guilty of it on our current website - trying to sell to both borrowers, stakeholders and federal partners all on the same website.

-CG, Pathway Lending 


\section{Online lenders hold an advantage over CDFIs in their ability to invest in online marketing and data analytics.}

Search engine optimization and keywords - paying for that is not a possibility for us. We can't compete with Dealstruck or Lending Club for ad space.

- CP, Pacific Community Ventures

If you look at the budget they have for marketing and the number of flyers and postcards. That's where they are getting the deals from.

-DH, The Support Center

When you give that all away, you have to take it from somewhere, and we all take it from marketing. That's the easiest place to take it. We're not going to have millions and millions of dollars for advertising or millions of dollars that we can throw at online advertising. It's not realistic to think the CDFI industry can get there.

-CG, Pathway Lending

Can we match the amount of money that online lenders are putting into customer acquisition? No, we really can't. We really can't spend the millions that they are spending to pay brokers, to do direct mail, all of the traditional methods that they are using.

- KC, CDC Small Business Finance

[It's] not just the technology. The technology is sort of like all software driven and building platforms that have different capabilities. But the analytical thing tells you and is a constant feedback loop which typically CDFIs are not, we're not set up for that. If you go to Lending Club or OnDeck, they are constantly getting information back from their borrowers. It's constantly coming in and they are constantly tweaking their model and their approach based on those analytics coming back.

—KC, CDC Small Business Finance

\section{CDFIs have unique capabilities that could help them continue to be relevant and impactful players in the business lending space, provided they can adapt to the new environment.}

One of these capabilities is the educational and technical assistance CDFIs provide to borrowers.

So CDFIs ... play a very important role within a small business ecosystem in their community especially as it relates to technical assistance.

-BM, Fundera

The CDFI is great for the educational piece.

-BE, Mirador 
CDFIs, given their high touch, given their boots on the ground, given their high community impact, are critically important to that ecosystem. Technology just backs that up.

-DG, OnDeck

If we charged our customers for all the technical assistance we give them for free, we'd be making a fortune.

-CG, Pathway Lending

I think that that is our biggest opportunity is to be able to teach the small business community to be wary of the predation of these fintech products that are out there because most business owners, all they're going to hear is "yes and here's your money" and they're not going to read the fine print, or not enough of it to understand the hole that they are digging themselves into.

-JE, Coastal Enterprises

[Take] Opportunity Fund or Accion. These guys, they've actually figured out a way to lend to businesses that have lower credit scores-the owners have lower credit scores, yet they are not getting the defaults that one would expect. That is what CDFIs can teach the online lending industry or can compete with the online lending industry in areas where they can really drive online lenders toward financial inclusion, which is key.

- JH, Community Investment Management

\section{Some interviewees saw CDFI "high touch" and community-based methods as differentiators that allow CDFIs to serve certain market segments other can't.}

We think our competitive advantage is in the high touch and our ability to listen to stories and understand what's going on with the borrower and educate them about their choices and alternatives that we don't believe works through a computer screen ... I don't believe that you can get the best possible solution for a client by doing this through automation and I don't believe that you can make a break and just assume that because someone is coming on line that they belong in an online lender.

-AK, Multifunding

Our hypothesis is that part of reaching additional borrowers is that CDFIs are going to do a better job at workouts and collections making it cost effective to lend at a higher risk than Lending Club would otherwise lend. Because they'll do the workout, they will be patient. They'll do the TA-that kind of thing.

-LCP, Lending Club 
In terms of a durable role for CDFIs, I think there are [several] classes of businesses that CDFIs are serving. 1) There's small businesses that could be served by the market right now, by the traditional market. And CDFIs serve that customer base is a way to subsidize other things that they are doing. 2) There's small businesses that now have market solutions with this online lending stuff that's happening that wasn't happening before. And CDFIs are basically gong to struggle to serve that population unless they a) have some reason for reaching that population and the online stuff isn't, which maybe they're reaching them through the local community folks or b) CDFIs can continue to serve customers that now have a market base solution in online lending - they're reaching these people because they're reaching them by adopting tools that online lenders use.

3) Is serving businesses without a market solution. No one but CDFIs can do this. —LCP, Lending Club

\section{At the same time, some observers felt that being "high touch" is not in and of itself a competitive advantage.}

I think what is happening to us is we're starting to realize as an industry and as a CDFI we've seen a lot of new studies that say the borrower doesn't care anymore. The borrower doesn't care that you are high touch.

-DH, The Support Center

There's a tradeoff between a) wanting to be a craftsman and really feel every deal uniquely, where you know them and you have the opportunity to customize terms and b) solving the gap of access to capital. You can't do both those things with the same approach.

-LCP, Lending Club

There's just this inherent kind of mythology that in the industry that the only way to serve hard-to-serve markets is by being idiosyncratic.

-EW, Opportunity Fund

\section{The fact that CDFIs generally offer affordably priced financing with transparent terms was seen as a potential advantage by several interviewees.}

CDFIs have a great product but they need to embrace the technology and they need to embrace the practices that speed up the processes.

- CK, Small Business Majority

What CDFIs are doing is so much better for the borrower ... That's where a strategic advantage ... of CDFIs is to differentiate ... the work that they do-the relationship that they have with borrowers and predatory practices. Or at least opaque practices ... And that means, they are going to have to invest in education and marketing.

- JH, Community Investment Management 
Does someone graduate from an online to a CDFI? I don't know.

-CGO, Calvert Foundation

[CDFIs] are doing refis on the unwinds [of loans from online lenders].

- RM, Kentucky Highlands Investment Corporation

\section{Fintech in general, and the growth of online business lending in particular, presents new opportunities for CDFIs to create new marketing channels, generate operating efficiencies, access capital, and improve customer service.}

There are three big headaches for CDFIs. The number one headache for them is how to get more customers ... the second challenge is that operation costs ... the third headache they have is capital. They constantly have to be looking out for (it). The new online lending technology can help them address all three.

- KH, Happy Mango

Online lending represents an opportunity to take ... innovation to streamline cost, to eliminate the very negative customer experience for borrowers, to find borrowers in new places and to cut out a lot of the barriers that are keeping loans away from creditworthy borrowers.

- JH, Community Investment Management

\section{A number of interviewees highlighted operating efficiencies in particular.}

What [fintech] is allowing CDFIs to do is be far more efficient in core operations and underwriting and the same concept our technology is providing to a lot of different scenarios, whether that's banks or CDFIs or other types of service providers, like Intuit. You can increase scale.

-DG, OnDeck

It's exciting that you can actually lend someone $\$ 40,000$ and make a profit compared to before they had to lend someone $\$ 200,000$ to make a profit.

-BE, Mirador

Technology automates and we all know that. And even though CDFIs-who like to see that human touch, that one on one relationship with their customers, there's still a lot of manual process that is repetitive; that is redundant; that is unnecessary for humans (to be doing) today. That's going to be replaced by online technology - and for that reason they ought to look into online lending systems. What kind of technology will give them the flexibility to keep their human touch but also take advantage of the benefits of technology such as automation, operating efficiency?

- KH, Happy Mango 
If I could get somebody to let me see their transactions into their business account, I can tell you whether I will lend them any money in 20 minutes-or less. That's where I think we as a CDFIs as an industry are way behind the curve, trying to do everything paper based.

—CG, Pathway Lending

\section{Interviewees also made more general comments about the benefits of embracing new technology.}

There's technology out there that's been vetted and it works. How can we get our hands on that? I think that's what we're starting to realize.

-DH, The Support Center

What CDFIs need (to do) to reach people in the first place is just to utilize the technology tools that are becoming available now.

-LCP, Lending Club

There's got to be a real exciting opportunity here to take some of this technology and overlay it onto CDFIs.

—CG, Pathway Lending

Interviewees saw various opportunities for CDFIs to garner new customers, through employing new technology and through partnerships with online lenders. However, some interviewees were skeptical about the possibility for meaningful partnerships with online lenders.

[With technology, CDFIs] can bring in more business and they can open their doors to different types of credit or at least different loan levels than they had in the past.

-BE , Mirador

Our underwriting platform and our model is very well suited to effectively being licensed or white-labeled for that kind of a partnership [with CDFIs]. -DG, OnDeck

OnDeck has a connection with Quickbooks where they can access senior data and in the application can offer a loan.

-JS, Coastal Enterprises

There's two different partnership models that we can do with CDFIs. One of them is that other CDFIs plug in to what we're doing with Opportunity Fund ... what we're looking for there is putting together a patchwork of national coverage with requirements for capital to invest through the partnership, and collections capacity particularly. The second kind of partnership is for the CDFI 
to use Lending Club's loan products white-labeled, as one tool on the shelf to serve their customers.

—LCP, Lending Club

I am very skeptical that we are ever going to create meaningful partnerships, true partnerships between CDFIs and online lenders. I think the fundamental motivations are not as aligned.

-CGO, Calvert Foundation

\section{Several interviewees also felt there was a customer acquisition opportunity to work with declined and/or former customers of online lenders. At the same time, some interviewees expressed concern about how viable some of these customers could be.}

CDFIs to us are a great customer, especially when we are talking about declines.

-BE, Mirador

We did have a couple of [borrowers] refinance their debt.

-DH, The Support Center

We started to see refugees, particularly from the merchant cash advance field. -AZ, Craft3

I'd say 15 percent [of our customers come as a result of online loan troubles]. But it's a lot. We often decline them. They're in too deep. And unfortunately, some of them I never hear from again.

- CP, Pacific Community Ventures

\section{Interviewees believed that some care and coordination is warranted as CDFIs consider whether to develop their own platforms or partner with others.}

I think what we are seeing in CDFI-land is that everybody is enamored with platforms. Everybody is building platforms without significant consideration. - TH, Association for Enterprise Opportunity

We want the CRF SPARK platform and I was phenomenally impressed because we were developing half of that ourselves in house.

-CG, Pathway Lending

[What is] missing from the CDFI sector is a shared infrastructure and a shared platform.

-NE, Community Reinvestment Fund 
The question really is, what are the options for CDFIs? They can either, to my point, build it themselves and there are in fact technology providers that can build them an online lending presence. That would be the Accion model. Or they can go with the Opportunity Fund model, which is partner with an online lender and say, "we're going to use you to help us find borrowers. We're going to bring our own special sauce. We're going to bring our own expertise around credit and servicing."

- $\mathrm{JH}$, Community Investment Management

The result of Opportunity Fund and AEO kind of being out there and starting to look at this was not everybody ran and said, "how do we collaborate on this?" Everybody ran and said, "how do I get my platform up?"

-KC, CDC Small Business Finance

\section{Much more of fintech's potential could be unleashed to the extent that a CDFI or CDFIs are able to offer a consistent set of products nationally.}

I think that we realized early on that trying to create idiosyncratic, one-off relationships with dozens, if not hundreds of individual CDFIs would be incredibly challenging.

-DG, OnDeck

Right now, [Fundera has] about 38 lenders. The problem [with putting a CDFI on the company's web site] then becomes the incremental burden versus the benefit to the customer.

-BM, Fundera

We don't have the same ability [with] CDFIs to understand any consistency in product. There is none, so it makes it very difficult. It's hard enough to do what we do. It's very difficult to understand the product suite of a CDFI ... and then to be able to train our people here ... "Well, that guy's calling from San Francisco, so there's a CDFI there with these five products." And if they're calling from Chicago, the CDFI there has those five products. It's tough, almost impossible ... -AK, Multifunding

The best thing that [CDFIs] could do is band together and select the one or two people to help them select the best technology, mindful of the group interest.

- KH, Happy Mango

CDFIs are not going to live and die by their ability in getting referrals from [brokers]. And the ability to get those, I think can be ... two approaches: the SBA Community Advantage program - they could probably become that if it's just presented in the right way and maybe people standardize their approach to that product or to 2) the extent that CDFIs partner with a Lending Club and have a CDFI version of a Lending Club loan product-that can be a 
standardized loan product and [brokers] that are API integrated with Fundera, it would be really easy for them to fund CDFIs.

-LCP, Lending Club

\section{Many, although not all, interviewees believe that CDFIs who are unable to adapt may be left behind-creating a concern about whether and how smaller CDFIs can participate in the fintech revolution.}

CDFIs have a prominent role to play but they are increasingly being marginalized by their inability to access the technology that's becoming table stakes to work with small business borrowers.

—LCP, Lending Club

The CDFIs that do not adapt are going to die. That's just the way that it is going to happen. They are tiny. They live on subsidy. We should allow consolidation and we should allow some of them to go out of business.

- JH, Community Investment Management

Every CDFI seems to think that what they are doing is unique and therefore they have to have all these vertically integrated organizations with $H R$ functions and marketing functions and underwriting functions and technology functions and you name it.

- NE, Community Reinvestment Fund

I think there is huge opportunity for efficiency gain within the CDFI industry. Alt-place lending is going to eat the lunch eventually of the CDFI business lenders.

-CGO, Calvert Foundation

\section{Many CDFIs and fintech companies remain unaware of one another, in the opinion of at least some observers.}

The fintech industry doesn't know us. So let's start with that.

-JS, Coastal Enterprises

They don't want to know us.

-JE, Coastal Enterprises

[The CDFI] industry sits there and remains oblivious to this. We're going to be in big trouble.

-FA, Community Reinvestment Fund 
A word cloud generated from interview transcripts is presented in Figure 4 below.

Figure 4: Word Cloud Generated from Interview Transcripts

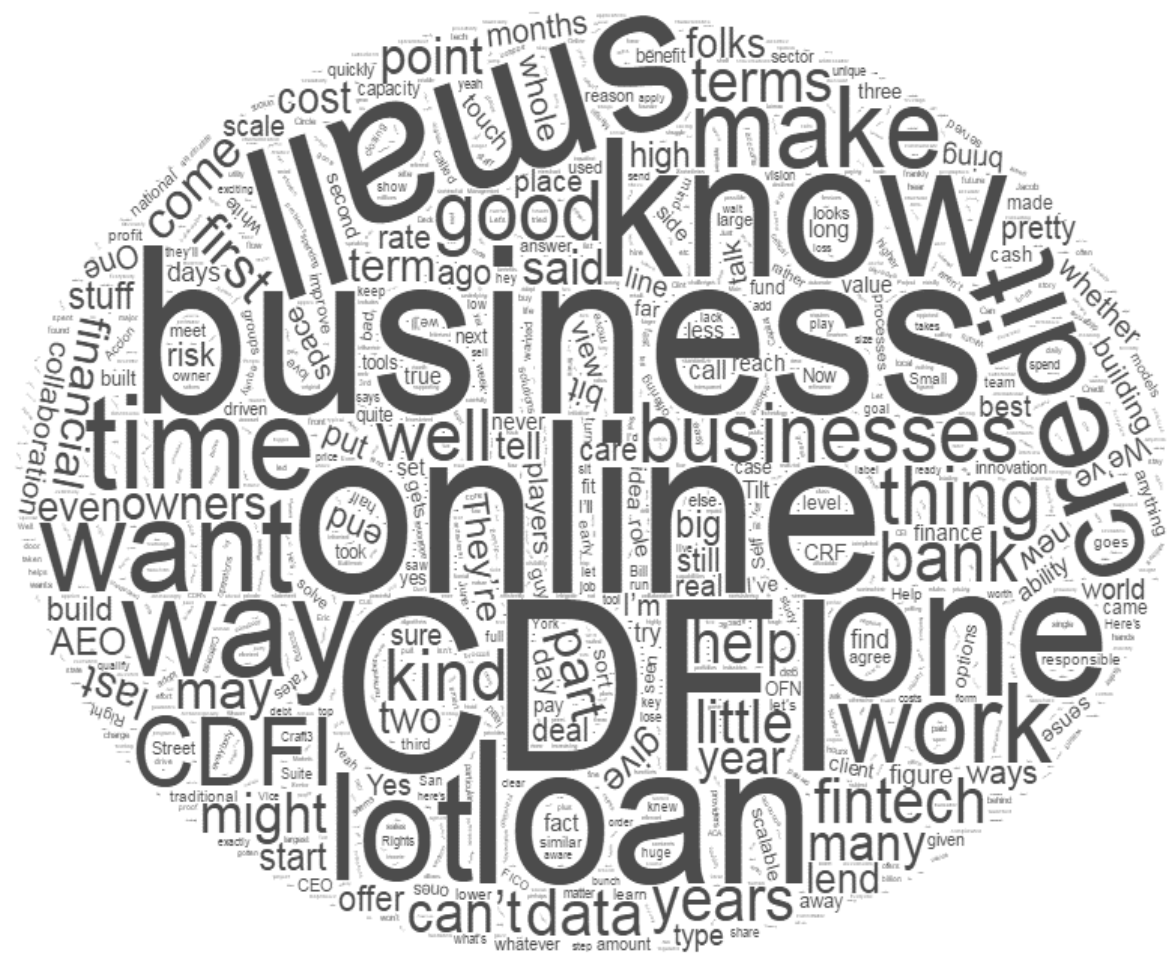

